\title{
Genetic Variability Influences Carotenoid, Vitamin, Phenolic, and Mineral Content in White, Yellow, Purple, Orange, and Dark-orange Carrot Cultivars
}

\author{
Catherine Nicolle 1 \\ Vilmorin Clause \& Cie, BP 1, 63720 Chappes, France \\ Gérard Simon \\ Vilmorin-Centre de recherche de La Costière, 30210 Ledenon, France \\ Edmond Rock \\ UMMM, INRA Clermont-Ferrand/Theix, 63122 Saint Genès Champanelle, France
}

Pierre Amouroux

Vilmorin Clause \& Cie, BP 1, 63720 Chappes, France

Christian Rémésy

UMMM, INRA Clermont-Ferrand/Theix, 63122 Saint Genès Champanelle, France

\begin{abstract}
AdDitional InDEX words. Daucus carota, colored carrot varieties, $\beta$-carotene, vitamin E, vitamin C, antioxidant compounds
Abstract. Carrot (Daucus carota $\mathrm{L}$.) is ranked among vegetables as the most consumed and the best provitamin $\mathrm{A}$ provider. Moreover, carrot also contains vitamins, phenolic compounds, and other antioxidant micronutrients. The influence of carrot genetic background on the content of several micronutrients was investigated. Carotenoids and vitamins ( $\mathrm{C}$ and $\mathrm{E}$ ) were analyzed by HPLC in 20 varieties of carrot, and antioxidant activity of carrots was investigated with colorimetric methods (ORAC and Folin-Ciocalteu). There were large differences among cultivars in carotenoid content $(0.32$ to $17 \mathrm{mg} / 100 \mathrm{~g}$ of fresh weight). In yellow and purple carrots, lutein represents nearly half of the total carotenoids. By contrast, in orange carrots, $\beta$-carotene represents the major carotenoid $(65 \%)$. The concentration of vitamin $\mathrm{E}$ ranged from 191 to $703 \mu \mathrm{g} / 100 \mathrm{~g}$ of fresh weight, whereas the concentration in ascorbic acid ranged from 1.4 to $5.8 \mathrm{mg} / 100 \mathrm{~g}$. For all these components, dark-orange carrots exhibited the highest values. Significant differences among these 20 varieties were also recorded for mineral and total phenolic compound concentrations. Purple and darkorange carrots could be preferred to usual carrot varieties to benefit from their specific micronutrients (anthocyanins, carotenoids, or vitamin E). ORAC is a complex reflection of phytomicronutrients but is not tightly linked to vitamin $\mathrm{C}$ levels, as shown for white carrots, which are rich in this vitamin.
\end{abstract}

Carrot belongs to the umbelliferae class; it is one of the most consumed plant food in the world in all seasons. Orange color is essential not only for carrots sold on the fresh vegetable market but also for the food industry. The main variation in the color of carrot is due to genotype, the development of the plant, the temperature during the growing season and also other agronomic practices such as the use of fertilizers (Bajaj et al., 1980; Van den Berg et al., 2000). Carrots are the major single source of pro-vitamin A, providing $14 \%$ to $17 \%$ of the total vitamin A consumption (Block, 1994; Heinonen, 1990). The main pigments of orange carrot are $\alpha$ - and $\beta$-carotene, but a few authors have described some types of carotene ( $\gamma$ - and $\xi$-carotene) and trace of lycopene (Simon and Wolff, 1987). Several studies showed that $\beta$-carotene conversion to vitamin $\mathrm{A}$ is faster compared to other carotenoids (van Vliet et al., 1996). Recently, $\beta$-carotene was proved to have anti-cancer activity related to its activity as a free radical quencher and antioxidant (Miller et al., 1996; Polyakov et al., 2001). Other authors reported the health impacts of fruits and vegetables rich in carotenoids consumption, and more particu-

Received for publication 16 Oct. 2003. Accepted for publication 9 Feb. 2004. We thank L. Ogier for kindly supplying grown carrots used in this study, J.C. Tressol for his help in minerals analysis, and P. Lamby for its contribution to the sampling. ${ }^{1}$ Also with UMMM, INRA Clermont-Ferrand/Theix, 63122 Saint Genès Champanelleo, France. To whom reprint requests should be addressed; e-mail remesy@clermont.inra.fr. larly $\beta$-carotene (Broekmans et al., 2001; Hirvonen et al., 2000; Jialal et al., 1991). Moreover, carrot contains other compounds, such as phenolic compounds (mainly caffeoyl ester) and organic acids (mainly malate and citrate), which contribute not only to the sensory qualities but have in addition nutritional properties for human health. Carrot contains also several mineral and trace elements. The intake of potassium, calcium, iron, and zinc, which are essential nutrients, is often insufficient in human diets.

To assist the breeding programs, it is necessary to analyze typical varieties in terms of minerals and micronutrient contents. Increasing the bioavailability of these elements in plant foods is particularly important for human nutrition.

The objective of this work was to examine the differences between several genotypes of carrot in their carotenoid, antioxidant vitamin content, total phenolic acids level and their mineral contents.

\section{Materials and Methods}

\section{Plant material}

Samples of 20 carrot cultivars, including white, yellow, orange, purple, and dark-orange carrots, were grown at the same location, in the south of France (Breeding unit of Vilmorin Clause \& Cie, La Costière, France). Genotypes included five commercial varieties for usual consumption (used as references). All genotypes were planted at the same time. The sampling period lasted from 
the end of November to mid-December, and followed an average growing period of 5 months outdoors under the same agricultural conditions. About 30 carrots per cultivar were randomly selected and stored in dark before sampling and analysis.

\section{Sampling}

Roots were washed and the median third of each carrot was grated. About $5 \mathrm{~g}$ were homogenized with $10 \mathrm{~mL}$ of $5 \%$ metaphosphoric acid and stored at $-80{ }^{\circ} \mathrm{C}$ until vitamin $\mathrm{C}$ analysis. Aliquants of this pool were stored at $-20^{\circ} \mathrm{C}$ until carotenoids and vitamin E analysis and the remainder of the pool was freeze-dried for minerals and Folin-Ciocalteu analysis.

\section{High-pressure liquid chromatography analysis for identification and quantification}

a-Carotenoids AND Vitamin E determination. Carotenoids were extracted at room temperature in plant samples as follows according an adaptation of the method developed by Tyssandier et al. (2003). In total, $700 \mathrm{mg}$ of carrot was treated with a mixture of $7 \mathrm{~mL}$ methanol containing the internal standard (echinenone) and $0.04 \mathrm{~g}$ of magnesium carbonate, $7 \mathrm{~mL}$ trichloromethane, and $5 \mathrm{~mL}$ water. After maceration of $20 \mathrm{~min}$ with regular agitation and centrifugation, the organic phase was removed and the remaining phase was extracted a second time with a mixture of dichloromethane $(5 \mathrm{~mL})$, tetrahydrofuran $(5 \mathrm{~mL})$ and water $(3 \mathrm{~mL})$. The two organic phases were pooled, evaporated and solubilized with $3 \mathrm{~mL}$ of acetonitrile-dichloromethane (50:50 by volume) for HPLC analysis.

Carotenoids and vitamin E were analyzed by HPLC and identified by comparing their retention times and UV-spectra with those of standards. The HPLC equipment included a photodiode array detector with a Waters Millemium software. The separation was carried out on a Vydac TP54 $(250 \times 4.6 \mathrm{~mm}$; Hesperia, Calif.) and a Nucleosil column $(150 \times 4.6 \mathrm{~mm}$; Interchim, Montluçon, France $)$ in series. Elution was performed with a mobile phase containing acetonitrile-methanol containing $50 \mathrm{~mm}$ ammonium acetate-dichloromethane-water (70:15:10:5 by volume), at a constant flow rate of $2 \mathrm{~mL} \cdot \mathrm{min}^{-1}$ as previously described (Lyan et al., 2001).

B-VITAMin C. Vitamin C was extracted from the previous homogenate of fresh carrot mixed with $90 \mathrm{~mL}$ of chilled metaphosphoric acid 5\% (p/v) (Sigma, St Louis, Mo). The mixture was crushed and centrifuged at $3400 \mathrm{~g}$ for $20 \mathrm{~min}$ at $4{ }^{\circ} \mathrm{C}$. Ascorbic acid was determined according to the method previously described by Tessier et al. (1996). Ascorbic acid from $500 \mu \mathrm{L}$ of supernatant was oxidized by $200 \mu \mathrm{L}$ of potassium ferricyanide ( 2 $\mathrm{g} \cdot \mathrm{L}^{-1}$; Sigma, St Louis) and sodium acetate buffer $\left(3.68 \mathrm{~mol} \cdot \mathrm{L}^{-1}\right.$; $\mathrm{pH}$ 6.9). The quinoxaline complex was formed with $200 \mu \mathrm{L}$ of ortho-phenylenediamine $\left(10 \mathrm{mg} \cdot \mathrm{mL}^{-1}\right.$; Sigma $)$. Dehydroascorbic acid was quantified by HPLC coupled with fluorescent detector (Alliance-Waters), using an Hypersil BDS-C18 column (5 $\mu \mathrm{m}$ to $25 \mathrm{~cm}$ ) at $30^{\circ} \mathrm{C}$. Elution was performed with a mobile phase $\left(\mathrm{Na}_{2} \mathrm{HPO}_{4} 80 \mathrm{mmol} \cdot \mathrm{L}^{-1}, \mathrm{NaH}_{2} \mathrm{PO}_{4} 80 \mathrm{mmol} \cdot \mathrm{L}^{-1}\right.$, and methanol, $30: 30: 40$ by volume) with a constant flow rate $\left(0.8 \mathrm{~mL} \cdot \mathrm{min}^{-1}\right)$. Excitation wavelength was $360 \mathrm{~nm}$ and emission wavelength was $440 \mathrm{~nm}$.

\section{Colorimetric measurements}

a-Phenolic Compounds. The amount of total phenolics in extracts was determined according to the modified Folin-Ciocalteu procedure (Singleton and Rossi, 1965). Freeze-dried samples (250 mg) were extracted with $10 \mathrm{~mL}$ of 70 acetone : 30 water (by volume) and then centrifuged for $20 \mathrm{~min}$ at $3400 \mathrm{~g}_{\mathrm{n}}$ at $4{ }^{\circ} \mathrm{C}$. The Folin reagent and aqueous $\mathrm{Na}_{2} \mathrm{CO}_{3}$ were successively added to the food extract diluted in $\mathrm{MeOH}-\mathrm{H}_{2} \mathrm{O}(150 \mu \mathrm{L})$. The mixture was kept in a water bath at $50{ }^{\circ} \mathrm{C}$ for $5 \mathrm{~min}$, then chilled on ice before reading the absorbance at $760 \mathrm{~nm}$. Gallic acid was used

Table 1. Carotenoids content in carrot (Daucus carota L.) cultivars. Extractions were carried out in triplicate for each cultivar.

\begin{tabular}{|c|c|c|c|c|c|c|}
\hline \multirow[b]{2}{*}{ Cultivar } & \multirow[b]{2}{*}{ Color } & Lutein & $\alpha$-carotene & $\beta$-carotene & Total carotenoids & \multirow{2}{*}{$\begin{array}{l}\text { Percent } \\
\text { of mean }\end{array}$} \\
\hline & & \multicolumn{4}{|c|}{$\mu \mathrm{g} / 100 \mathrm{~g}$ (fresh weight) } & \\
\hline$\overline{\text { Hyb 1z }}$ & Orange & $94 \pm 4$ afy & $1972 \pm 183 \mathrm{ad}$ & $5433 \pm 462 \mathrm{ag}$ & $9374 \pm 565 a$ & 114 \\
\hline New Kuroda & Orange & $93 \pm 3$ af & $1635 \pm 17 \mathrm{ac}$ & $3632 \pm 64 \mathrm{bd}$ & $6448 \pm 650 b$ & 78 \\
\hline Carentan & Orange & $145 \pm 14$ bdf & $1644 \pm 50 \mathrm{ac}$ & $5932 \pm 360 \mathrm{ac}$ & $9684 \pm 792 \mathrm{a}$ & 118 \\
\hline $\operatorname{Hyb} 2^{z}$ & Orange & $164 \pm 29 b$ & $3131 \pm 263 b$ & $6653 \pm 564 c$ & $12524 \pm 492 \mathrm{c}$ & 152 \\
\hline Hyb $3^{z}$ & Orange & $60 \pm 7 \mathrm{a}$ & $1419 \pm 99 \mathrm{cg}$ & $4149 \pm 112 \mathrm{bg}$ & $9588 \pm 734 \mathrm{a}$ & 117 \\
\hline Kokubu & Orange & $161 \pm 4 b$ & $1748 \pm 29 \mathrm{ac}$ & $3740 \pm 25$ bd & $8351 \pm 565 a$ & 102 \\
\hline Hyb 4z & Orange & $157 \pm 8$ bf & $2291 \pm 224 d$ & $6190 \pm 403 \mathrm{ac}$ & $11435 \pm 317 \mathrm{c}$ & 139 \\
\hline San Naï & Orange & $180 \pm 5 b$ & $1333 \pm 85 \mathrm{c}$ & $3206 \pm 182 d$ & $6648 \pm 472 b f$ & 81 \\
\hline Blanche des Vosges & White & $\mathrm{ND}^{\mathrm{x}}$ & $\mathrm{ND}$ e & $\mathrm{ND}$ e & $\mathrm{ND} d$ & --- \\
\hline $\mathrm{HCM}$ & Dark-orange & $103 \pm 14$ adf & $7583 \pm 619 f$ & $17206 \pm 643 \mathrm{f}$ & $26548 \pm 1436 \mathrm{e}$ & 323 \\
\hline Violette jordanienne & Purple & $224 \pm 9 \mathrm{e}$ & $\mathrm{ND} e$ & $381 \pm 24 \mathrm{e}$ & $605 \pm 32 \mathrm{~d}$ & 7 \\
\hline Blanche à collet vert & White & ND c & $\mathrm{ND}$ e & $\mathrm{ND}$ e & ND d & --- \\
\hline Yellowstone & Yellow & $232 \pm 12 \mathrm{e}$ & $\mathrm{ND} e$ & $332 \pm 15 \mathrm{e}$ & $563 \pm 19 d$ & 7 \\
\hline Jaune obtuse du Doubs & Yellow & $138 \pm 24$ bdf & $\mathrm{ND} e$ & $332 \pm 21 \mathrm{e}$ & $469 \pm 45 \mathrm{~d}$ & 6 \\
\hline Hyb 5z & Orange & $116 \pm 14 \mathrm{bf}$ & $1916 \pm 138 \mathrm{adg}$ & $4730 \pm 319 \mathrm{~g}$ & $9414 \pm 539 a$ & 114 \\
\hline Violette turque & Purple & $176 \pm 19 b$ & $\mathrm{ND}$ e & $318 \pm 18 \mathrm{e}$ & $493 \pm 36 d$ & 6 \\
\hline De Guérande & Orange & $161 \pm 28 b$ & $1278 \pm 234 \mathrm{c}$ & $3354 \pm 457 \mathrm{bd}$ & $5998 \pm 389 b$ & 73 \\
\hline Hyb $6^{z}$ & Orange & $157 \pm 8 b$ & $2322 \pm 233 d$ & $5404 \pm 305 \mathrm{ag}$ & $11944 \pm 550 \mathrm{c}$ & 145 \\
\hline La Merveille & Orange & $175 \pm 9 b$ & $2092 \pm 36 d$ & $5869 \pm 101 \mathrm{ac}$ & $9663 \pm 794 a$ & 118 \\
\hline $\begin{array}{l}\text { Nantaise améliorée } \\
\text { Mean }\end{array}$ & Orange & $\begin{array}{c}61 \pm 8 \mathrm{a} \\
144\end{array}$ & $\begin{array}{c}1369 \pm 150 \mathrm{c} \\
1858\end{array}$ & $\begin{array}{c}3625 \pm 329 \mathrm{bd} \\
4471\end{array}$ & $\begin{array}{c}8138 \pm 590 \text { af } \\
8219\end{array}$ & 100 \\
\hline
\end{tabular}

zCommercial French hybrids (Hyb).

y Means followed by same letter in column are not significantly different $(P<0.05)$.

$\times \mathrm{ND}=$ not detected 
Table 2. Vitamin E and vitamin C content in carrot cultivars (extractions were carried out in triplicate for each cultivar) and total phenolic acids based on Folin-Ciocalteu assay and antioxidant activities of lipophilic extracts based on ORAC assay. Extractions were carried out in duplicate.

\begin{tabular}{|c|c|c|c|c|c|c|c|}
\hline Cultivar & Color & $\begin{array}{l}\text { Vitamin } \\
\mathrm{E} \\
(\mu \mathrm{g} / 100 \mathrm{~g} \\
\text { fresh } \mathrm{wt})\end{array}$ & $\begin{array}{c}\text { Percent } \\
\text { of } \\
\text { mean }\end{array}$ & $\begin{array}{l}\text { Vitamin } \\
\mathrm{C} \\
\text { (mg/100 g } \\
\text { fresh wt) }\end{array}$ & $\begin{array}{l}\text { Percent } \\
\text { of } \\
\text { mean }\end{array}$ & $\begin{array}{c}\text { Total } \\
\text { phenolic } \\
\text { acids } \\
\text { (mg of gallic acid } \\
\text { equivalent/g dry wt) }\end{array}$ & $\begin{array}{c}\text { ORAC } \\
\mu \text { mol of trolox/ } \\
\mathrm{g} \text { fresh } w \mathrm{t})\end{array}$ \\
\hline$\overline{\mathrm{Hyb} 1^{z}}$ & Orange & $218 \pm 20 a^{y}$ & 53.8 & $2.6 \pm 0.02 \mathrm{a}$ & 82.3 & $3.3 \pm 0.03$ & $10.5 \pm 2.2$ \\
\hline New Kuroda & Orange & $438 \pm 28$ bhj & 108.1 & $2.1 \pm 0.00 \mathrm{~b}$ & 68.0 & $5.9 \pm 0.09$ & $9.1 \pm 0.8$ \\
\hline Carentan & Orange & $425 \pm 12 \mathrm{bhj}$ & 105.0 & $2.0 \pm 0.04 \mathrm{bl}$ & 63.3 & $3.8 \pm 0.05$ & $9.2 \pm 2.0$ \\
\hline $\operatorname{Hyb} 2^{z}$ & Orange & $396 \pm 18$ bih & 97.8 & $3.2 \pm 0.01 \mathrm{c}$ & 110.3 & $4.6 \pm 0.10$ & $8.7 \pm 0.6$ \\
\hline Hyb $3^{z}$ & Orange & $355 \pm 6$ cei & 87.6 & $1.6 \pm 0.01 \mathrm{~d}$ & 51.9 & $3.9 \pm 0.08$ & $8.0 \pm 1.7$ \\
\hline Kokubu & Orange & $383 \pm 25 b c$ & 94.6 & $3.6 \pm 0.11 \mathrm{e}$ & 114.6 & $6.0 \pm 0.3$ & $8.6 \pm 2.2$ \\
\hline Hyb4z & Orange & $324 \pm 17$ ce & 79.9 & $1.7 \pm 0.01 \mathrm{~d}$ & 53.7 & $3.5 \pm 0.09$ & $10.5 \pm 1.6$ \\
\hline San Naï & Orange & $524 \pm 5 d$ & 129.5 & $3.6 \pm 0.02 \mathrm{e}$ & 114.3 & $4.4 \pm 0.02$ & $8.9 \pm 2.1$ \\
\hline Blanche des Vosges & White & $314 \pm 12 \mathrm{e}$ & 77.5 & $5.1 \pm 0.05 \mathrm{f}$ & 161.5 & $3.4 \pm 0.06$ & $3.6 \pm 0.7$ \\
\hline $\mathrm{HCM}$ & Dark-orange & $703 \pm 17 f$ & 173.4 & $5.8 \pm 0.02 \mathrm{~g}$ & 182.5 & $5.1 \pm 0.08$ & $14.8 \pm 1.7$ \\
\hline Violette jordanienne & Purple & $625 \pm 9.4 \mathrm{~g}$ & 154.3 & $2.5 \pm 0.01 \mathrm{a}$ & 78.0 & $16.9 \pm 0.4$ & $7.3 \pm 1.1$ \\
\hline Blanche à collet vert & White & $191 \pm 8 \mathrm{a}$ & 47.2 & $4.7 \pm 0.20 \mathrm{~h}$ & 149.8 & $3.3 \pm 0.08$ & $4.6 \pm 0.5$ \\
\hline Yellowstone & Yellow & $593 \pm 44 \mathrm{~g}$ & 146.4 & $1.7 \pm 0.01 \mathrm{i}$ & 127.0 & $4.3 \pm 0.02$ & $8.5 \pm 0.8$ \\
\hline Jaune obtuse du Doubs & Yellow & $456 \pm 14 \mathrm{hj}$ & 112.6 & $5.3 \pm 0.12 \mathrm{j}$ & 168.0 & $4.4 \pm 0.05$ & $8.1 \pm 1.0$ \\
\hline Hyb 5z & Orange & $340 \pm 19$ cei & 84.0 & $1.4 \pm 0.01 \mathrm{k}$ & 45.7 & $3.5 \pm 0.03$ & $11.1 \pm 2.8$ \\
\hline Violette turque & Purple & $383 \pm 55 \mathrm{bc}$ & 94.5 & $4.7 \pm 0.00 \mathrm{~h}$ & 149.0 & $9.6 \pm 0.28$ & $8.4 \pm 0.3$ \\
\hline De Guérande & Orange & $357 \pm 22$ cei & 88.0 & $2.1 \pm 0.02 \mathrm{bl}$ & 66.8 & $3.4 \pm 0.1$ & $8.7 \pm 1.4$ \\
\hline Hyb $6 z$ & Orange & $394 \pm 4$ bih & 97.1 & $1.7 \pm 0.01 \mathrm{~d}$ & 52.4 & $4.0 \pm 0.03$ & $10.4 \pm 1.1$ \\
\hline La Merveille & Orange & $476 \pm 10 \mathrm{dj}$ & 117.6 & $3.4 \pm 0.02 \mathrm{e}$ & 109.4 & $3.9 \pm 0.03$ & $9.0 \pm 1.2$ \\
\hline $\begin{array}{l}\text { Nantaise améliorée } \\
\text { Mean }\end{array}$ & Orange & $\begin{array}{c}208 \pm 23 \mathrm{a} \\
405\end{array}$ & 51.3 & $\begin{array}{c}1.9 \pm 0.001 \\
3.2\end{array}$ & 61.6 & $4.5 \pm 0.06$ & $10.5 \pm 1.5$ \\
\hline
\end{tabular}

${ }^{\mathrm{z} C o m m e r c i a l ~ F r e n c h ~ h y b r i d s ~(H y b) . ~}$

yMeans followed by same letter in column are not significantly different $(P<0.05)$.

to establish the calibration curve and total phenolic content was expressed as gallic acid equivalent.

b-OXYGEN RADICAL ABSORPTION CAPACITY ASSAY (ORAC). The semi-automated ORAC assay was carried out on a Perkin Elmer spectrofluorometer with fluorescent filters $\left(\lambda_{\text {ex }} 540 \mathrm{~nm} ; \lambda_{\text {em }} 565\right.$ $\mathrm{nm})$. The procedure was based on a previous report by Cao et al. (1996) except for the extraction conditions. The experiment was conducted at $37{ }^{\circ} \mathrm{C}$ with a blank in parallel. The analyzer was programmed to record the fluorescence of $\beta$-PE every minute after addition of AAPH [2,2'-azo-bis(2-amidinopropane)dihy drochloride sulfate], a peroxyl radical generator. Results were expressed as $\mu \mathrm{mol}$ Trolox equivalents per gram.

\section{Mineral measurements}

The carrots were freeze-dried and the dry weights were determined. Aliquants of carrot powder $(250 \mathrm{mg})$ were dry-ashed overnight at $500{ }^{\circ} \mathrm{C}$ (with a progressive increase from 25 to 500 ${ }^{\circ} \mathrm{C}$ ). The ash was dissolved in concentrated nitric acid and $0.2 \mathrm{~mL}$ of $\mathrm{H}_{2} \mathrm{O}_{2}$. Then, the temperature was progressively increased to $150{ }^{\circ} \mathrm{C}$ and the dry residue was dissolved by $100 \mu \mathrm{L}$ of pure nitric acid $\left(\mathrm{HNO}_{3}\right)$ and diluted with $100 \mathrm{~mL}$ of distilled water. Minerals and trace elements were measured by flame atomic absorption spectrometry (Perkin Elmer AA 800), after an appropriate sample dilution in $1 \%$ nitric acid acetylene-air flame.

\section{Statistical analyses}

Values are given as the means \pm SEM, and the differences between values were determined by one-way analysis of variance coupled with the Student-Newman-Keuls multiple-comparison test. Values of $P<0.05$ were considered significant.

\section{Results}

Carotenoids. Four major carotenoids were detected from colored cultivars (yellow, purple, or orange): lutein, $\alpha$-carotene, $\beta$-carotene, and its isomer 13 cis $\beta$-carotene. Yellow and purple varieties contained only lutein and $\beta$-carotene whereas no carotenoids could be detected in white cultivars (Table 1). The predominant carotenoid in all samples was $\beta$-carotene accounting for $43 \%$ to $71 \%$ of the total carotenoids and $\alpha$-carotene accounting for $17 \%$ to $22 \%$ of total carotenoids. Similar values have been reported in previous studies (Heinonen, 1990; Simon and Wolff, 1987). Therefore, only lutein and $\alpha$ - and $\beta$-carotene were quantified due to their relatively high abundance, as compared to other carotenes present in carrots. Although lutein does not account for a large part of total carotenoids ( $0.4 \%$ to $2.7 \%$ ), lutein represents $29 \%$ to $41 \%$ of the total carotenoids in yellow and purple carrots. Carotenoid levels in purple and yellow carrots vary from 469 to $605 \mu \mathrm{g} / 100 \mathrm{~g}$, whereas 10 times more carotenoids were found in orange carrots. The dark-orange cultivar contained the highest amount of carotenoids, especially $\beta$-carotene $(17 \mathrm{mg} / 100 \mathrm{~g})$, whereas the purple cultivar was the poorest in $\beta$-carotene $(0.32$ $\mathrm{mg} / 100 \mathrm{~g}$ ) together with white cultivars.

Vitamin E. Data about the inter-variety difference of vitamin E content in carrots are scarce. In the present work, we have identified an important impact of genotype on $\alpha$-tocopherol content (Table 2 ). There was a 3.7 factor between the richest and the poorest cultivars in $\alpha$-tocopherol. Three cultivars contained more than $600 \mu \mathrm{g} / 100 \mathrm{~g}$ of fresh weight: one yellow, one purple, and one dark-orange. Three others (one white cultivar and two orange cultivars) contained very low amount of $\alpha$-tocopherol; their content was 2 -fold lower than values given by food composition table. 
Table 3. Minerals and trace elements in carrot content. Extractions were carried out in duplicate for each cultivar.

\begin{tabular}{|c|c|c|c|c|c|c|c|}
\hline \multirow[b]{2}{*}{ Cultivar } & \multirow[b]{2}{*}{ Color } & \multirow{2}{*}{$\begin{array}{c}\mathrm{K} \\
(\mathrm{mg} / 100 \mathrm{~g} \text { fresh } \mathrm{wt})\end{array}$} & $\mathrm{Na}$ & $\mathrm{Mg}$ & $\mathrm{Ca}$ & $\mathrm{Fe}$ & $\mathrm{Zn}$ \\
\hline & & & \multicolumn{5}{|c|}{$(\mathrm{mg} / 100 \mathrm{~g}$ fresh $\mathrm{wt})$} \\
\hline$\overline{\text { Hyb } 1^{z}}$ & Orange & $515 \pm 12 \operatorname{acd}^{y}$ & $17.6 \pm 0.7 \mathrm{ac}$ & $8.9 \pm 0.2 \mathrm{a}$ & $33.8 \pm 0.1 \mathrm{al}$ & $0.65 \pm 0.02 \mathrm{ad}$ & $0.24 \pm 0.02 \mathrm{abd}$ \\
\hline New Kuroda & Orange & $498 \pm 3$ abi & $24.0 \pm 0.3 b$ & $8.0 \pm 0.1 \mathrm{a}$ & $27.2 \pm 0.2 \mathrm{bj}$ & $0.54 \pm 0.01 \mathrm{ad}$ & $0.25 \pm 0.01$ ace \\
\hline Carentan & Orange & $519 \pm 4$ ade & $16.6 \pm 0.5 \mathrm{ac}$ & $15.1 \pm 0.1 b$ & $35.5 \pm 0.1 \mathrm{cf}$ & $0.62 \pm 0.01 \mathrm{abf}$ & $0.24 \pm 0.00 \mathrm{abf}$ \\
\hline $\operatorname{Hyb} 2^{z}$ & Orange & $542 \pm 13 a b$ & $16.4 \pm 0.6 \mathrm{ac}$ & $10.6 \pm 0.2 \mathrm{c}$ & $29.0 \pm 0.9 b$ & $0.76 \pm 0.01 \mathrm{bg}$ & $0.25 \pm 0.01$ aef \\
\hline $\mathrm{Hyb} 3^{z}$ & Orange & $443 \pm 14 \mathrm{ac}$ & $26.8 \pm 1.0 \mathrm{~b}$ & $8.5 \pm 0.0 \mathrm{~d}$ & $32.7 \pm 0.1 \mathrm{cfh}$ & $0.55 \pm 0.01 \mathrm{ad}$ & $0.18 \pm 0.01 \mathrm{bd}$ \\
\hline Kokubu & Orange & $745 \pm 0.3 \mathrm{bf}$ & $17.5 \pm 0.1 \mathrm{ae}$ & $12.9 \pm 0.1 \mathrm{c}$ & $44.3 \pm 0.4 \mathrm{ch}$ & $1.45 \pm 0.06 \mathrm{c}$ & $0.39 \pm 0.05$ ce \\
\hline $\operatorname{Hyb} 4 z$ & Orange & $465 \pm 7 c$ & $18.2 \pm 0.7 \mathrm{c}$ & $9.5 \pm 0.0 \mathrm{dl}$ & $31.0 \pm 0.2 \mathrm{dj}$ & $0.50 \pm 0.01 \mathrm{~d}$ & $0.19 \pm 0.01 \mathrm{~d}$ \\
\hline San Naï & Orange & $633 \pm 18 b f$ & $20.9 \pm 1.1 \mathrm{c}$ & $11.2 \pm 0.2 \mathrm{c}$ & $35.5 \pm 0.6$ ajk & $1.22 \pm 0.15$ ce & $0.28 \pm 0.00$ aef \\
\hline Blanche des Vosges & White & $619 \pm 8$ bdf & $37.8 \pm 0.2 \mathrm{~d}$ & $17.0 \pm 0.0 \mathrm{~b}$ & $39.6 \pm 0.7 \mathrm{ch}$ & $0.79 \pm 0.02 \mathrm{abg}$ & $0.28 \pm 0.04$ aef \\
\hline $\mathrm{HCM}$ & Dark-orange & $693 \pm 8$ ad & $14.4 \pm 0.1 \mathrm{e}$ & $23.1 \pm 0.1 \mathrm{e}$ & $44.6 \pm 0.4 \mathrm{ak}$ & $1.36 \pm 0.03 \mathrm{e}$ & $0.36 \pm 0.01$ ace \\
\hline Violette jordanienne & Purple & $613 \pm 37$ bef & $19.4 \pm 0.1 \mathrm{c}$ & $9.9 \pm 0.0 \mathrm{dl}$ & $42.6 \pm 0.1 \mathrm{e}$ & $0.69 \pm 0.05 \mathrm{abfg}$ & $0.31 \pm 0.00 \mathrm{eg}$ \\
\hline Blanche à collet vert & White & $611 \pm 19 \mathrm{f}$ & $39.7 \pm 1.1 \mathrm{f}$ & $14.8 \pm 0.0 \mathrm{f}$ & $37.1 \pm 0.4 \mathrm{f}$ & $0.54 \pm 0.01 \mathrm{df}$ & $0.26 \pm 0.01$ aef \\
\hline Yellowstone & Yellow & $601 \pm 4 \mathrm{fi}$ & $26.6 \pm 0.6 b$ & $11.5 \pm 0.0 \mathrm{~g}$ & $38.1 \pm 0.1 \mathrm{f}$ & $0.77 \pm 0.01 \mathrm{~g}$ & $0.24 \pm 0.01 \mathrm{ad}$ \\
\hline Jaune obtuse du Doubs & Yellow & $640 \pm 13 \mathrm{bf}$ & $17.7 \pm 1.9 \mathrm{ac}$ & $13.6 \pm 0.2 \mathrm{~h}$ & $39.8 \pm 0.1 \mathrm{hk}$ & $0.73 \pm 0.09 \mathrm{ag}$ & $0.26 \pm 0.02 \mathrm{ad}$ \\
\hline Hyb 5z & Orange & $509 \pm 7$ ade & $34.6 \pm 0.4 \mathrm{fd}$ & $10.4 \pm 0.0 \mathrm{i}$ & $33.7 \pm 0.0 \mathrm{k}$ & $0.50 \pm 0.01 \mathrm{df}$ & $0.20 \pm 0.01 \mathrm{df}$ \\
\hline Violette turque & Purple & $521 \pm 4$ bdf & $61.6 \pm 3.5 \mathrm{~g}$ & $10.5 \pm 0.1 \mathrm{~g}$ & $44.9 \pm 0.3 \mathrm{i}$ & $1.98 \pm 0.04 \mathrm{i}$ & $0.24 \pm 0.02 \mathrm{afg}$ \\
\hline De Guérande & Orange & $758 \pm 68$ ade & $27.8 \pm 1.8 b$ & $10.7 \pm 0.04 \mathrm{~g}$ & $28.8 \pm 0.3 \mathrm{j}$ & $0.32 \pm 0.02 \mathrm{j}$ & $0.22 \pm 0.03 \mathrm{ad}$ \\
\hline Hyb $6^{z}$ & Orange & $512 \pm 2$ ade & $23.4 \pm 0.3 b$ & $13.5 \pm 0.0 \mathrm{k}$ & $35.5 \pm 0.4 \mathrm{cf}$ & $0.54 \pm 0.00 \mathrm{dfj}$ & $0.23 \pm 0.01 \mathrm{ad}$ \\
\hline La Merveille & Orange & $604 \pm 23$ bef & $37.6 \pm 2.5 \mathrm{~d}$ & $10.4 \pm 0.21$ & $36.4 \pm 0.6 \mathrm{k}$ & $0.72 \pm 0.01 \mathrm{agj}$ & $0.24 \pm 0.02 \mathrm{ad}$ \\
\hline Nantaise améliorée & Orange & $545 \pm 3 a b$ & $33.6 \pm 0.8 \mathrm{~d}$ & $11.4 \pm 0.0 \mathrm{~g}$ & $31.7 \pm 0.41$ & $0.62 \pm 0.04 \mathrm{ad}$ & $0.22 \pm 0.01 \mathrm{df}$ \\
\hline Mean & & 579 & 26.6 & 12.1 & 36.1 & 0.79 & 0.25 \\
\hline
\end{tabular}

zCommercial French hybrids (Hyb).

yMeans followed by same letter in column are not significantly different $(P<0.05)$.

Table 4. Correlation between micronutrients.

\begin{tabular}{lll}
\hline Parameter & \multicolumn{1}{c}{$\beta$-carotene } & \multicolumn{1}{c}{ Total carotenoids } \\
\hline$\alpha$-tocopherol & $r^{2}=0.44 ; P<0.0001$ & $r^{2}=0.42 ; P<0.0001$ \\
ORAC assay & $r^{2}=0.638 ; P<0.0001$ & $r^{2}=0.654 ; P<0.0001$ \\
\hline
\end{tabular}

The white lines contained low amounts of vitamin $\mathrm{E}$, whereas the other yellow and purple lines had medium concentrations.

VITAMIN C. In the present survey on 20 varieties of carrots, vitamin C content varied from 1.44 to $5.75 \mathrm{mg} / 100 \mathrm{~g}$ (Table 2 ). We observed an important influence of the genotype on the ascorbic acid content. The ascorbic acid content was much greater in the dark-orange (4 times), yellow (3.7 times), or white (3.4 times) cultivars than in orange carrots.

Amount of total PHENolics. The amount of total phenolic acids varied widely in plant materials and ranged from 3.3 to $16.9 \mathrm{mg}$ of GAE/g of dry weight (gallic acid equivalent) (Table 3). Among fresh material, low levels of phenolics were found in white cultivars ( 3.3 to $3.4 \mathrm{mg} \mathrm{GAE} / \mathrm{g}$ of dry weight), in yellow (4.3 to $4.4 \mathrm{mg} \mathrm{GAE} / \mathrm{g}$ dry weight), and in orange cultivars (from 3.3 to $6.0 \mathrm{mg} \mathrm{GAE} / \mathrm{g}$ dry weight), whereas purple cultivars contained higher amounts of phenolics (9.6 and $16.9 \mathrm{mg} \mathrm{GAE} / \mathrm{g}$ dry weight).

AnTIOXIDANT ACTIVITy. The antioxidant activities against peroxyl radicals (ROO*) generated by AAPH in 20 cultivars of carrot are summarized in Table 3. Based on fresh weight, the dark orange had the highest ORAC values. Most of the orange cultivars had ORAC values that fell in the average $(8.9 \mu \mathrm{mol}$ Trolox Equivalent/gram fresh weight), whereas the white cultivars had the lowest ORAC values. We note the absence of difference between yellow, purple and most of the orange lines.

Minerals and trace elements. Table 4 and Fig. 1B illustrate the variability of minerals and trace elements among the cultivars. The most important mineral in carrot is potassium. We observed a marginal influence of the cultivar on the potassium content (a factor of 1.7 between the richest and the poorest one). By contrast, the sodium content varied widely among the cultivars, there was 6.2 times more sodium in the richest than in the poorest. Calcium accumulation seems to be less affected by the cultivar than magnesium or iron. Iron content was from 31 to $199 \mathrm{mg} \cdot \mathrm{kg}^{-1}$ of dry weight. Other trace element accumulations also seem to be affected by cultivar: copper range was from 4.0 to $6.3 \mathrm{mg} \cdot \mathrm{kg}^{-1}$ dry weight and range of zinc concentration was from 17 to 29 $\mathrm{mg} \cdot \mathrm{kg}^{-1}$ dry weight. There was no correlation between color and mineral or trace element contents. However, the dark orange cultivar ranked relatively high for each mineral or trace element content, excepted for potassium. We noted a direct relationship between iron and calcium $(P=0.0016)$.

\section{Discussion}

Fruits and vegetables are known to play a key role in prevention of several diseases. Because of their health-promoting effects, nutritional recommendations favor a high consumption of fruits and vegetables. However, it is important that these plant-foods have an optimal composition of micronutrients to exert their beneficial effects. For a long time, carrot breeding was performed on agronomic and organoleptic criteria. It is important to consider if breeding could take account of carrot variability in micronutrients to improve their health promoting effects.

Micronutrient Contents variations. Carotenoids are the major micronutients in carrots. In our study, carotenoid levels varied widely among cultivars from 0 in white carrots to 17 $\mathrm{mg} / 100 \mathrm{~g}$ fresh weight in the dark-orange carrot. The highest values of $\beta$-carotene are similar to values previously described in literature for the same variety $(25 \mathrm{mg} / 100 \mathrm{~g}$ ) (Simon and Wolff, 1987). Our results from purple lines differ from of those reported by Alasalvar et al. (2001), namely $\approx 2.2$ times more $\alpha$ - 

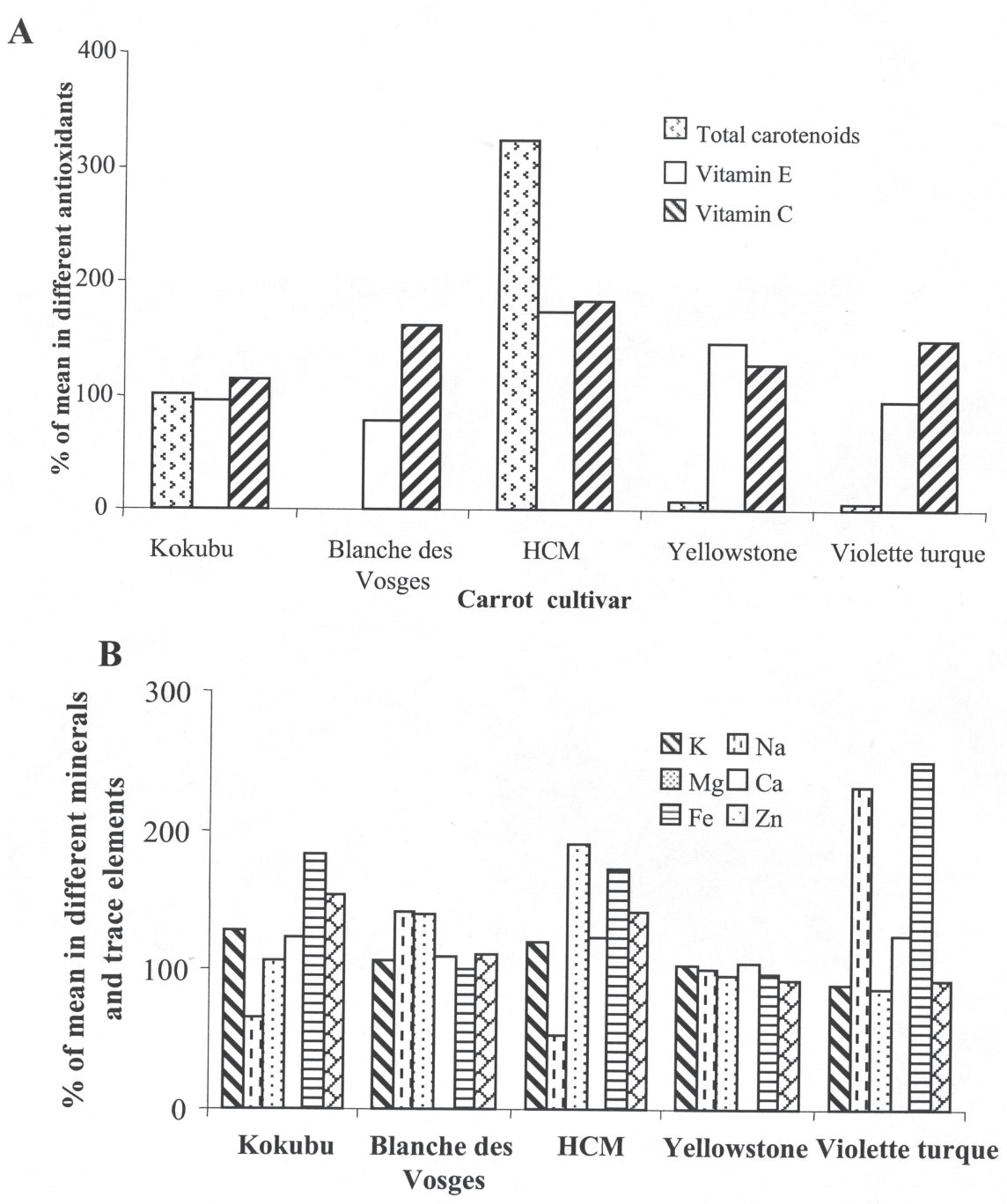

Carrot cultivar
Vitamin $\mathrm{C}$ is essential in all vegetables. Although, carrot is not an evident source of vitamin $\mathrm{C}$, in this survey carrots contains an average of $3.2 \mathrm{mg} / 100 \mathrm{~g}$ of vitamin C. Our data are lower than those reported in food composition tables (Souci et al., 2000) or by other authors (McErlain et al., 2001; Singh et al., 2001) but are closer to those described by Favell (1998) (range from 2.8 to $4.5 \mathrm{mg} / 100 \mathrm{~g}$ ) or Alasalvar et al. (2001) (range from 1.25 to $5.33 \mathrm{mg} / 100 \mathrm{~g}$ ). The relatively low values observed in this study, compared to the literature, are due to the exclusion of dehydroascorbic acid (oxidized form of ascorbic acid) in the calculation of total vitamin $\mathrm{C}$ content. In our study, the variations observed are explained by the genotype, but the difference between our values and those in the literature might be explained partly by the environmental condition. The harvest year was particularly wet, which could be responsible for the low levels of vitamin C. As expected from its antioxidant-based functions in plant metabolism, the levels of ascorbic acid are responsive to a variety of environmental (stress) factors, namely light, temperature, salt and drought stress, atmospheric pollutants, metals, or herbicides. For example, it has been reported that herbicides may exert an effect on the chemical composition of carrot, stimulating the synthesis of some of the phytonutrients (sugars, vitamin C) and decreasing the formation of others (such as carotene) (Villeneuve and Leteinturier, 1992). Low temperatures also influence the size of the ascorbic acid pool suggesting a clear relationship with the antioxidative contents of plants.

Phenolic acids represent a marginal part of the micronutrient contents in orange carrots,

Fig. 1. Antioxidant (A) and minerals (B) profile of typical carrot cultivars.

and $\beta$-carotene in purple varieties than in orange carrot. Together with variety, location, and year, genotype influences not only the total carotenoid content but also the proportions of each species ( $\alpha$ - and $\beta$-carotene in carrots). This observation was reported by Desobry et al. (1998). In yellow or purple carrots, lutein represents nearly half of the total carotenoids. By contrast, in orange carrot $\beta$-carotene represents the major carotenoid (65\%). The carotenoid content of plants can be increased substantially by genetic manipulation, either by traditional plant breeding or by genetic engineering. Fertilization practices also affect the accumulation of carotenoids, whose levels in vegetables also vary depending on the maturity at harvest. The high variability of carotenoid levels due to the genotype and the possibility of a reliable determination by HPLC-diode array favor the inclusion of this parameter in the plant breeding program (Simpson, 1983).

In carrots, vitamin E content is 10-fold lower than carotenoid. With the exception of the dark-orange, orange carrots contained vitamin $\mathrm{E}$ amounts similar to those as described in food tables (between 324 to $525 \mu \mathrm{g} / 100 \mathrm{~g}$ ) (Souci et al., 2000). However, we observed differences in vitamin E contents between the poorest and the richest orange lines (62\%). whereas anthocyanins in purple carrots are not negligible. The values observed in our work are in accordance with a previous report for carrot (6.6 mg GAE/g dry weight) (Kähkönen et al., 1999). However, carrot is a marginal source of phenols in comparison to berries (12.4 to $50.8 \mathrm{mg} \mathrm{GAE} \mathrm{mg} \cdot \mathrm{g}^{-1}$ dry weight) or various leafy vegetables (Vinson et al., 1998). The major phenolic acids contained in carrots are the 5-caffeoylquinic acid, 3,5-dicaffeoylquinic acid, 3,4-dicaffeoylquinic acid, or 5-feruloylquinic acid (Alasalvar et al., 2001). A previous study indicated the presence of two main anthocyanins: cyanidin-3-lathyroside and cyanidin-3- $\beta$-D-glucopyranoside in the callus culture. The same anthocyanins were recovered in carrot explants but in lower amounts (Narayan and Venkataraman, 2000). Some authors have also reported different glucosides of cyanidin, malvidin and peonidin (Glabgen et al., 1992).

We investigated the antioxidant activity of the 20 cultivars by the ORAC assay. The difference observed were less conclusive than the study of each antioxidant molecule. Our ORAC values seemed to be higher than in Cao's study (Cao et al., 1996) but our extraction was more specific for carotenoids and vitamin $\mathrm{E}$ than extraction with distilled water. However, our values, converted on a weight dry basis, were closer to those found by $\mathrm{Ou}$ et al. (2002) (45 to $80 \mu \mathrm{mol} \mathrm{TE} / \mathrm{g}$ dry weight). In our study the range 
was from 30 to $102 \mu \mathrm{mol} \mathrm{TE/g} \mathrm{dry} \mathrm{weight.} \mathrm{These} \mathrm{authors} \mathrm{carried}$ out their extraction with acetone, which is more lipophilic, thus carotenoids and vitamin E could be extracted and contribute to the ORAC values.

Our data on mineral contents suggest that iron, sodium and magnesium levels are highly influenced by variety whereas potassium and calcium are less dependent on genetic background. Previous studies have reported calcium contents from $0.20 \%$ to $0.32 \%$ of the dry weight and magnesium contents from $0.08 \%$ to $0.13 \%$ of the dry weight (Villeneuve and Leteinturier, 1992). We observed a range of calcium content from 2.7 to $4.5 \mathrm{~g} \cdot \mathrm{kg}^{-1}$ dry weight compared to the range of magnesium content: from 0.8 to $1.6 \mathrm{~g} \cdot \mathrm{kg}^{-1}$ dry weight. The total concentration of Fe, $\mathrm{Zn}$, and $\mathrm{Ca}$ in edible parts of plants can be increased in three ways: by applying fertilizers, by plant breeding and by genetic engineering (Frossard et al., 2000). Modern cultivars of wheat and rice contain lower concentrations of $\mathrm{Fe}$ and $\mathrm{Zn}$ than traditional varieties (Graham et al., 1999), we can avoid such a drift for carrots. Crop selection has been mainly aimed at increasing yield and disease resistance but not improving the micronutrient concentration. In this context, it could be interesting to increase the mineral contents in carrots by including in breeding programs traditional varieties, or wild or primitive parents of cultivated crops that have a higher ability to accumulate minerals. Genetic engineering approaches could be used to increase both the level and the bioavailability of minerals in plant foods.

\section{Correlation between micronutrients}

A significant relationship between $\alpha$-tocopherol and $\beta$-carotene and between $\alpha$-tocopherol and total carotenoids contents was observed in orange carrots (Table 5). Indeed, carotenoids and vitamin E share a common precursor (geranylgeranyl diphosphate, GGPP) and probably a common regulating mechanism of their biosynthesis pathway (Armstrong and Hearst, 1996; Sandmann, 1994). This suggests a higher capacity of some lines to mobilize GGPP further involved in biosynthesis or it may result from higher enzymatic activity.

\section{Are micronutrients levels related to color root?}

As expected, carotenoid contents were highly correlated with root color. The darker orange roots had higher carotenoid levels. Such an observation was found between antioxidant activity measured by ORAC and the intensity of orange color in carrot. We observed a similar relation between the intensity of purple color and the total phenolic compounds. Overall, carrots with a strong purple color had higher phenolic contents than the yellow or the white varieties. The strongly colored carrots are rich in anthocyanins, and strong antioxidant activities for anthocyanins in different models have been reported (Rice-Evans et al., 1995) indicating a higher antioxidant capacity in such carrots.

\section{Carrot importance for intake of several micronutrients in our western diets}

The screening of carrot cultivars for nutritional quality is justified not only by the effectiveness of carrot ingestion to afford a good status in vitamin A but also by the intrinsic health effect of carotenoids (Bub et al., 2000; Gaziano, 1994). Carotenoids are important dietary factors involved in skin protection, in sight and antioxidant reactions (Faure et al., 1999). One serving of carrots rich in carotenoid each day is sufficient to satisfy the French recommended daily supply of vitamin A (600-800 retinol equivalent/day). However, the question arises as to the optimal level which could be reached in the future in carrots. The highest levels ( $>25 \mathrm{mg} / 100 \mathrm{~g}$ ) could be considered as nonnutritional supplementation. Since a large part of the general population has an insufficient dietary supply of carotenoids $\left(<3 \mathrm{mg} \cdot \mathrm{d}^{-1}\right)$, it seems desirable to improve the carotenoid levels of carrot cultivars. It is noteworthy that high concentrations of the three main antioxidants ( $\beta$-carotene, vitamin $\mathrm{E}$, and vitamin $\mathrm{C}$ ) could be found in a given cultivar. It could be interesting to verify if the consumption of varieties with marked differences in antioxidant activity induce significant variations in plasma antioxidant capacity. In this case, the breeders could include the variation of antioxidant activity in their scheme of selection. The possibility of developing a cultivar rich in lycopene could also be interesting in countries where tomato availability is limited.

As for carotenoids, vitamin $\mathrm{E}$ intake is frequently insufficient in most populations and it is largely provided by plant oil. The impact of carrot consumption on vitamin $\mathrm{E}$ status is quite limited, however it seems interesting to attempt to increase vitamin $\mathrm{E}$ levels in parallel to those carotenoids by plant breeding.

Increasing the level of vitamin $\mathrm{C}$ in carrots as well as in potatoes (15 to $30 \mathrm{mg} / 100 \mathrm{~g}$ ) for example, may have a beneficial impact on human health.

Carrot consumption seems to play a marginal role in calcium and magnesium supply. By contrast, the richness in iron of several carrot cultivars could be interesting for iron intake if it is bioavailable. One of the two purple varieties has a high capacity for iron storage, possibly linked to polyphenol synthesis. A high level of potassium is required to counteract the effect of sodium and to protect against hypertension. Carrots, like various roots and leguminous seeds, are an excellent source of potassium. Human populations that exhibit deficiencies or low intakes of vitamin $\mathrm{A}, \mathrm{Fe}$, and $\mathrm{Zn}$ are usually nourished primarily by plant foods. Increasing the levels of micronutrients in plant foods would therefore be expected to have a positive effect on human health. However, ascorbic acid enhances the uptake of Fe by human subjects. Increasing the ascorbic acid content of plant foods might therefore contribute to alleviating Fe deficiencies in human populations.

\section{Recommendations and priorities for plant breeders}

Among micronutrients, it is clear that the carotenoid levels may be one of the major points of breeding. The question rises of a maximal level to attempt. Theoretically, by contrast to vitamin A, carotenoids do not exert toxic effects, at least from vegetable sources. However, it could be beneficial to reach carotenoid concentrations close to those of dark-orange carrots ( $26 \mathrm{mg} / 100 \mathrm{~g}$ ). Presently, the phenolic content of carrot is not a priority for breeding, but phenolic compounds could exert an interesting role for carrot resistance to various environmental stresses. Because of the low concentration of ascorbic acid in current varieties, specific breeding work could be done to improve the content of vitamin $\mathrm{C}$.

In conclusion, strategies to limit the widespread micronutrient deficiencies that occur in human populations may involved plant selection. It seems that carrot breeding could ensure an optimal level of carotenoids as well as of other antioxidants and minerals to yield vegetables with optimal nutritional value. The inheritance of carotenoids, vitamins, phenolic acids, or various micronutrients has not been sufficiently investigated. An understanding of the genetic regulation of these parameters would facilitate breeding of new cultivars with specific micronutrients composition. 


\section{Literature Cited}

Alasalvar, C., J.M. Grigor, D. Zhang, P.C. Quantick, and F. Shahidi. 2001. Comparison of volatiles, phenolics, sugars, antioxidant vitamins, and sensory quality of different colored carrot varieties. J. Agr. Food Chem. 49:1410-1416.

Armstrong, G.A. and J.E. Hearst. 1996. Carotenoids 2: Genetics and molecular biology of carotenoid pigment biosynthesis. Faseb J. 10: 228-237.

Bajaj, K.L., G. Kaur, and B.S. Sukhija. 1980. Chemical composition and some plant characteristics in relation to quantity of some promising cultivars of carrot (Daucus carota L.). Qual. Plant-Plant. Foods Human Nutr. 30:97-107.

Block, G. 1994. Nutrient sources of provitamin A carotenoids in the American diet. Amer. J. Epidemiol. 139:290-293.

Broekmans, W.M., W.A. Klopping-Ketelaars, C. Kluft, H. van den Berg, F.J. Kok, and G. van Poppel. 2001. Fruit and vegetables and cardiovascular risk profile: A diet controlled intervention study. Eur. J. Clin. Nutr. 55:636-642.

Bub, A., B. Watzl, L. Abrahamse, H. Delincee, S. Adam, J. Wever, H. Muller, and G. Rechkemmer. 2000. Moderate intervention with carotenoid-rich vegetable products reduces lipid peroxidation in men. J. Nutr. 130:2200-2206.

Cao, G., E. Sofic, and R.L. Prior. 1996. Antioxidant capacity of tea and common vegetables. J. Agr. Food Chem. 44:3426-3431.

Desobry, S.A., F.M. Netto, and T.P. Labuza. 1998. Preservation of betacarotene from carrots. Crit. Rev. Food Sci. Nutr. 38:381-396.

Faure, H., V. Fayol, C. Galabert, P. Grolier, G. Le Moël, J.P. Steghens, A. Van Kappel, and F. Nabet. 1999. Les caroténoïdes: I. Métabolisme et physiologie. Ann. Biol. Clin. 57:169-183.

Favell, D.J. 1998. A comparison of the vitamin C content of fresh and frozen vegetables. Food Chem. 62:56-64.

Frossard, E., M. Bucher, F. Mächler, A. Mozafar, and R. Hurrell. 2000. Review: Potential for increasing the content and bioavailability of Fe, $\mathrm{Zn}$ and $\mathrm{Ca}$ in plants for human nutrition. J. Sci. Food Agr. 80:861-879.

Gaziano, J.M. 1994. Antioxidant vitamins and coronary artery disease risk. Amer. J. Med. 97:18S-21S, 22S-28S.

Glabgen, W.E., V. Wray, D. Strack, J.W. Metzger, and H.U. Seitz. 1992. Anthocyanins from cell suspension cultures of Daucus carota. Phytochemistry 31:1593-1601.

Graham, R.D., D. Senadhira, S. Beebe, C. Iglesias, and I. Monasterio. 1999. Breeding for micronutrient density in edible portions of staple food crops: Conventional approaches. Field Crops Res. 60:57-80.

Heinonen, M.I. 1990. Carotenoids and provitamin A activity of carrot (Daucus carota L.) cultivars. J. Agr. Food Chem. 38:609-612.

Hirvonen, T., J. Virtamo, P. Korhonen, D. Albanes, and P. Pietinen. 2000. Intake of flavonoids, carotenoids, vitamins $\mathrm{C}$ and $\mathrm{E}$, and risk of stroke in male smokers. Stroke 31:2301-2306.

Jialal, I., E.P. Norkus, L. Cristol, and S.M. Grundy. 1991. Beta-Carotene inhibits the oxidative modification of low-density lipoprotein. Biochim Biophys Acta 1086:134-138.

Kähkönen, M.P., A.I. Hopia, H.J. Vuorela, J.P. Rauha, K. Pihlaja, T.S. Kujala, and M. Heinonen. 1999. Antioxidant activity of plant extracts containing phenolic compounds. J. Agr. Food Chem. 47:3954-3962.

Lyan, B., V. Azais-Braesco, N. Cardinault, V. Tyssandier, P. Borel, M.C. Alexandre-Gouabau, and P. Grolier. 2001. Simple method for clinical determination of 13 carotenoids in human plasma using an isocratic high-performance liquid chromatographic method. J. Chromatogr. B Biomed. Sci. Appl. 751:297-303.

McErlain, L., H. Marson, P. Ainsworth, and S.A. Burnett. 2001. Ascorbic acid loss in vegetables: Adequacy of a hospital cook-chill system. Intl. J. Food Sci. Nutr. 52:205-211.

Miller, N.J., J. Sampson, L.P. Candeias, P.M. Bramley, and C.A. RiceEvans. 1996. Antioxidant activities of carotenes and xanthophylls. FEBS Lett 384:240-242.

Narayan, M.S. and L.V. Venkataraman. 2000. Characterisation of anthocyanins derived from carrot (Daucus carota) cell culture. Food Chem. 70:361-363.

Ou, B., D. Huang, M. Hampsch-Woodill, J.A. Flanagan, and E.K. Deemer. 2002. Analysis of antioxidant activities of common vegetables employing oxygen radical absorbance capacity (ORAC) and ferric reducing antioxidant power (FRAP) assays: A comparative study. J. Agr. Food Chem. 50:3122-3128.

Polyakov, N.E., T.V. Leshina, T.A. Konovalova, and L.D. Kispert. 2001. Carotenoids as scavengers of free radicals in a Fenton reaction: Antioxidants or pro-oxidants? Free Rad. Biol. Med. 31:398-404.

Rice-Evans, C.A., N.J. Miller, P.G. Bolwell, P.M. Bramley, and J.B. Pridham. 1995. The relative antioxidant activities of plant-derived polyphenolic flavonoids. Free Rad. Res. 22:375-383.

Sandmann, G. 1994. Carotenoid biosynthesis in microorganisms and plants. Eur. J. Biochem. 223:7-24.

Simon, P.W. and X.Y. Wolff. 1987. Carotenes in typical and dark orange carrots. J. Agr. Food Chem. 35:1017-1022.

Simpson, K.L. 1983. Relative value of carotenoids as precursors of vitamin A. Proc. Nutr. Soc. 42:7-17.

Singh, G., A. Kawatra, and S. Sehgal. 2001. Nutritional composition of selected green leafy vegetables, herbs and carrots. Plant Foods Human Nutr. 56:359-364.

Singleton, V.L. and J.A.J. Rossi. 1965. Colorimetry of total phenolics with phosphomolybdic-phosphotungstic acid reagents. Amer. J. Enol. Viticult. 16:144-158.

Souci, S.W., W. Fachmann, and H. Kraut. 2000 Food composition and nutrition tables. $6^{\text {th }}$ revised and completed ed. Medpharm Sci. Publ.

Tessier, F., I. Birlouez-Aragon, C. Tjani, and J.C. Guilland. 1996. Validation of a micromethod for determining oxidized and reduced vitamin $\mathrm{C}$ in plasma by HPLC-fluorescence. Intl. J. Vitamin Nutr. Res. 66:166-170.

Tyssandier, V., E. Reboul, J.F. Dumas, C. Bouteloup-Demange, M. Armand, J. Marcand, M. Sallas, and P. Borel. 2003. Processing of vegetable-borne carotenoids in the human stomach and duodenum. Amer. J. Physiol. Gastrointest. Liver Physiol. 284:G913-923.

Van den Berg, H., R. Faulks, H.F. Granado, J. Hirschberg, B. Olmedilla, G. Sandmann, S. Southon, and W. Stahl. 2000. The potential for the improvement of carotenoid level in foods and the likely systemic effects. J. Sci. Food Agr. 80:880-912.

van Vliet, T., F. van Schaik, W.H. Schreurs, and H. van den Berg. 1996. In vitro measurement of beta-carotene cleavage activity: Methodological considerations and the effect of other carotenoids on beta-carotene cleavage. Intl. J. Vitamin Nutr. Res. 66:77-85.

Villeneuve, F. and J. Leteinturier. 1992 La Carotte, guide pratique. Tomes 1 and 2. Ed. du CTILF-Sileban, Paris.

Vinson, J.A., Y. Hao, X. Su, and L. Zubik. 1998. Phenol Antioxidant Quantity and Quality in foods: Vegetables. J. Agr. Food Chem. 46:3630-3634. 